\title{
Characterization of Exopolysaccharides Produced by Marine Bacillus Megaterium
}

\author{
P. Ramya, D, Sangeetha
}

\begin{abstract}
Exopolysaccharides (EPSs) are polymers with large molecular weight that consist of various residues of sugar. These are desired because the substitution of synthetic polymers is degradable and non-toxic. Most microorganisms have the ability to synthesize and excrete exo polysaccharides with new chemical compositions, characteristics and structures in order to have important applications in various areas. The current study based on marine bacterial isolates screening the production of exo polysaccharide. Among the four exopolysaccharide producing isolates, the isolate PMSS12 had the highest production of exo polysaccharides. The efficient marine bacterial isolate PMSS12 was further identified by sequence of 16S rRNA. The PMSS12 isolate was confirmed as Bacillus megaterium. Then the exopolysaccharide produced by Bacillus megaterium was characterized by using FTIR, NMR and SEM.
\end{abstract}

Keywords: Exopolysaccharides, $16 S$ rRNA, Bacillus megaterium

\section{INTRODUCTION}

Biologically active natural molecules trigger a great deal of interest in finding new pharmaceutical medications [1.2]. The marine environment protects a wide range of natural products and can fulfill industrial and clinical applications [3,4]. The EPS is ubiquitous in the marine ecosystem owing to its survivability and competition of marine bacteria in minimal nutrients and unfavorable environments. [5,6].

Microorganisms have an original chemical composition of glycol polymers and exciting biological processes in addition to various aquatic sources (seaweeds, animals, invertebrates). [7,8,9,10]. Marine biotechnology has still not attained an economically important area but it is a successful sector for the maintenance of useful macro molecules $[11,12,13] . E P S$ from extremophilic microorganisms especially halophiles are comparatively less reported[14,15,16,17,18]. Production of EPS from halophilic bacteria within extreme marine habitat along with its biological activities was reviewed [19,2021,22,23].

In certain scenarios, the nutritional conditions can also influence the molecular weight and the EPS osidic

Revised Manuscript Received on October 25, 2019.

P. Ramya, Department of Microbiology,Faculty of Science,

Annamalai University, Annamalainagar- 608002, Tamilnadu, India.

D Sangeetha*, Department of Microbiology,Faculty of Science,

Annamalai University, Annamalainagar- 608002, Tamilnadu, India.

*Corresponding author E-Mail: sangeethadau@gmail.com composition. It has been shown that a novel Alteromonas macleodii strain produces $23.4 \mathrm{~g} / \mathrm{L}$ exo polysaccharide when grown on $15 \%$ of lactose, the highest yield for marine EPS $[24,25,26,27,28,29]$.

\section{MATERIALS AND METHODS}

\section{A. Collection of samples}

Marine sediment sample was collected from coastal area of Pichavaram, Tamilnadu, India.

\section{B. Isolation of marine bacterial cultures}

The collected sediment sample was diluted up to $10^{-7}$ by serial dilution technique. The $10^{-6}$ was inoculated by spread plate technique on Zobell Marine Agar plates. The plates were marked properly and kept in the incubator at $30^{\circ} \mathrm{C}$ for 48 hours. Morphologically different colonies with mucoid surface were picked and sub cultured for future use.

\section{Screening of polysaccharide production}

All the isolated mucoid colonies of marine bacteria were subjected to screening for EPS production. The screening was achieved by improving the Sayyed et al protocol. Zobell medium of Marine Ager was prepared by dissolving $0.75 \mathrm{gm}$ of yeast extract, $3 \mathrm{gm}$ of malt extract, $1.25 \mathrm{gm}$ of peptone, $0.25 \mathrm{gm}$ of monosodium glutamate and $7.5 \mathrm{gm}$ of sucrose. The water $\mathrm{pH}$ was set to 7.0 as well as $125 \mathrm{~mL}$ of marine water and $125 \mathrm{~mL}$ of distilled water and placed into petriplates after sterilization. On the solidified medium are streaked the bacterial strains to be tested for the production of EPS. At room temperature, the plates were incubated for 3 days, the production of EPS was indicated by the oozing of gum substances on the periphery of the bacterial colonies.

\section{Exopolysaccharide Production and Recovery}

For exo polysaccharide production the screened isolates were further evaluated. The inoculum was prepared by passing bacterial colony to $250 \mathrm{ml}$ conical flask containing $50 \mathrm{ml}$ Zobell Marine Broth and 5\% $\mathrm{NaCl}$. Inoculated flasks are incubated at a temperature of $37^{\circ} \mathrm{C}$ at $100 \mathrm{rpm}$ for 96 hours. The Zobell marine broth was cell-free at 10,000 rpm $\mathrm{f}$ or 20 minutes by centrifugation. Cold absolute ethanol was added to the supernatant in the ratio of $1: 3(\mathrm{v} / \mathrm{v})$ and kept at 4 $\mathrm{oC}$ for 24 hours (Kim and Yim, 2007) for precipitation of exo polysaccharide. 
The precipitates were recovered by centrifugation and purified by washing with Mille Q water. Finally, the exopolysaccharide was again precipitated by $1: 3$ volume of cold absolute alcohol and exopolysaccharide pellet were dried at $60^{\circ} \mathrm{C}$.

\section{E. Molecular Identification Of Efficient Exopolysaccharide Producing Isolate}

\section{Extraction of bacterial genomic DNA}

Bacteria are grown at $37^{\circ} \mathrm{C}$ for 24 hours in Zobell marine broth. Activated cultures were collected in $2 \mathrm{ml}$ microfuge tube and centrifuged at $10,000 \mathrm{rpm}$ at $4^{\circ} \mathrm{C}$ for 10 minutes. Further DNA extraction, precipitation and purification were carried out as per manufacture protocol of HiPer Bacterial Genomic DNA Extraction Kit (Hi-media Laboratory Pvt. Ltd. Mumbai). DNA from isolate was electrophoresed in $0.8 \%$ Agarose gel and visualized on a Gel Documentation System (Genie, Bangalore).

\section{F. $\quad 16 S \quad$ TRNA SEQUENCING IDENTIFICATION OF ISOLATE:}

FOR

The identification of isolate was made by evaluating similarity index, total score, query coverage and E-value. The sequence of $16 \mathrm{~S}$ rRNA achieved was submitted to the National Center for Biotechnology Information through the NCBI Sequence Submission Wizard. (https://submit.ncbi.nlm.nih.gov/subs/genbank).

Phylogenetic tree using neighbor joining algorithm was constructed to determine taxonomic position of the isolate.

\section{G. EXOPOLYSACCHARIDES PRODUCED BY BACILLUS MEGATERIUM CHARACTERIZATION}

\section{Fourier transform-infrared (FTIR) analysis}

The Exo polysaccharides functional groups analysis was determined using FTIR spectrophotometer. A sample of EPS was mixed with $\mathrm{KBr}$ in the ratio of 1:100 to form a $\mathrm{KBr}$ pellet with a dimension of $1 \mathrm{~mm}$ in thickness. The absorbance spectrum of EPS was determined in the wavelength range of $4000-5000 \mathrm{~cm}^{-1}$. The FTIR analysis was performed using Bruker FTIR instrument at IIT (Indian Institute of Technology, Chennai).

\section{$H$.}

\section{H AND 13C NMR ANALYSIS}

EPS structural elucidation was calculated using ${ }^{1} \mathrm{H}$ and ${ }^{13} \mathrm{C}$ NMR spectrum analysis. The NMR spectra measurements were performed using JEOL JNMECA 500 NMR spectrophotometer at IIT (Indian Institute of Technology, Chennai). The sample was dissolved in D2O. The sample spectrum was recorded at $500 \mathrm{MHz}$ in the ${ }^{1} \mathrm{H}$ NMR and 125.7 $\mathrm{MHz}$ in the ${ }^{13} \mathrm{C}$ NMR. The delay time was $5 \mathrm{~s}$ for ${ }^{1} \mathrm{H}$ NMR and $2 \mathrm{~s}$ for ${ }^{13} \mathrm{C}$ NMR.

\section{SCANNING ELECTRON MICROSCOPIC ANALYSIS}

Scanning electron microscopic analysis (SEM) determined the morphology of dried EPSs. EPS were coated on gold particles during the scanning of the electron micrograph at $3000 \mathrm{X}$ and micrograph was visualized. EPSs were taken in full and the view and structure of the surface were studied.

\section{RESULTS AND DISCUSSION}

\section{A.Exopolysaccharide production}

A total of 14 morphologically different marine bacterial cultures were isolated and screening was done for the efficiency to produce extracellular polysaccharides. Out of 14 , only four bacterial isolates were produced EPS. Further the four bacterial isolates were analyzed to check the polysaccharide content. The marine isolate PMSS12 exhibited maximum yield of exopolysaccharides (4.3 g/l).

Selim et al., 2018 reported that 18 isolates were isolated from the Ageeba beach sediment (MarsaMatrooh Governorate) and 9 isolates only produced EPS. Due to its maximum EPS production $\left(8.25 \mathrm{~g} \mathrm{~L}^{-1}\right)$, strain number five was chosen for further analysis.

Table.1 Exopolysaccharide production of the marine bacterial isolates

\begin{tabular}{|l|c|c|}
\hline S.No & Marine Isolates & $\begin{array}{l}\text { Exopolysaccharide } \\
(\mathbf{g} / \mathbf{l})\end{array}$ \\
\hline 1. & YMSSS & 2.3 \\
\hline 2. & PMSS5 & 2.5 \\
\hline 3. & PMSS7 & 2.1 \\
\hline 4. & PMSS12 & 4.3 \\
\hline
\end{tabular}

B.Phylogenetic analysis of Efficient Marine Isolate (PMSS12)

The strain producing highest amount of EPS was characterized by phylogenetic analysis. Phylogenetic analysis revealed that the marine bacterium PMSS12 was Bacillus Megaterium.

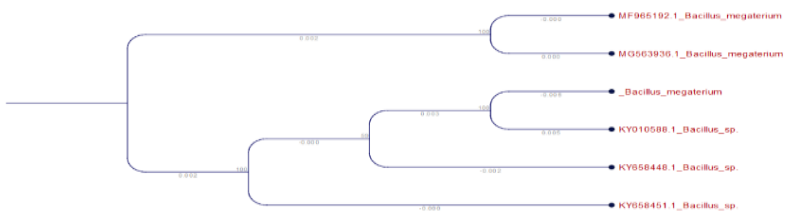

Fig.2 Phylogenetic tree of the Marine Isolate PMSS12

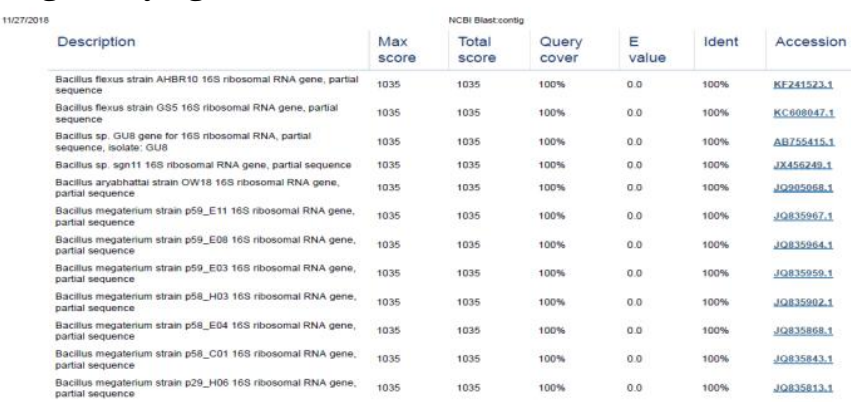

Fig.316S rRNA Sequence of Marine Isolate PMSS12 submitted to NCBI.

Published By: 


\section{C.CHARACTERIZATION OF EXOPOLYSACCHARIDES}

Fourier transform-infrared Exopolysaccharide

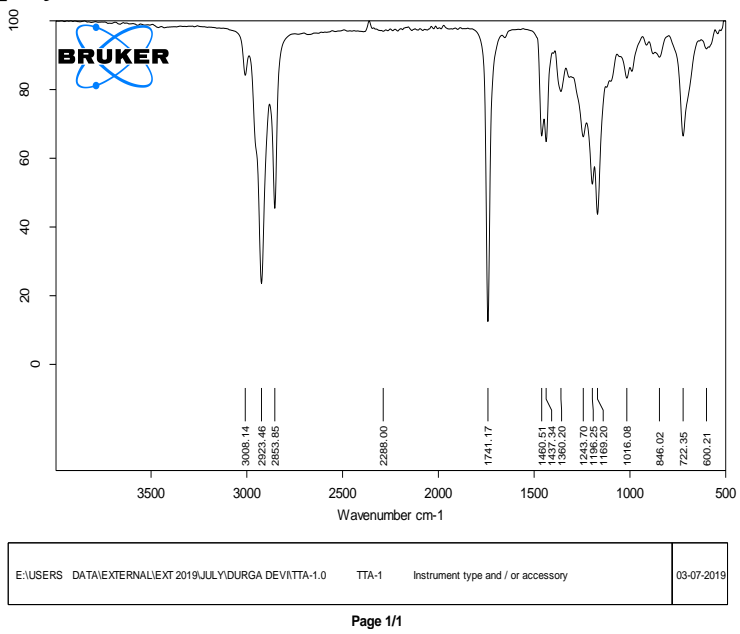

Fig. 4 FTIR Spectrum of Exopolysaccharides produced by Bacillus megaterium (PMSS12)

\section{NMR analysis of Exopolysaccharides}

EPS sample ${ }^{1} \mathrm{H}$ NMR spectrum revealed signals between the 3,659 to $4,932 \mathrm{ppm}$ ranges suggesting protons of anomeric carbons indicating the sample as heptasaccharide. The 3,361 ppm signal is consistent with the existence of protonated carbon adjacent to the electronegative group. The signal was applicable to protonated carbon adjacent to less electronegative groups at 2,506 ppm (Siddharth et al., 2017).

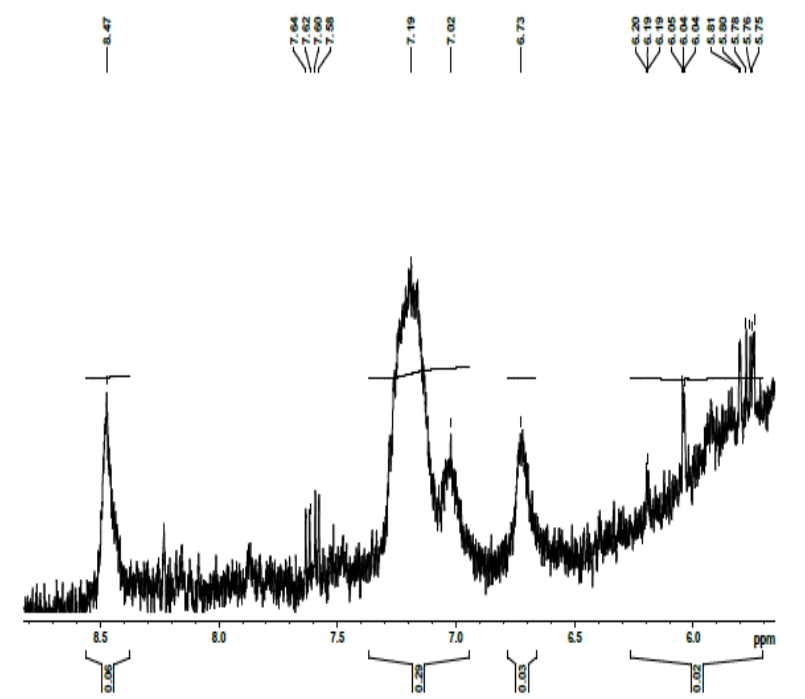

Fig. $5^{1} \mathrm{H}$ NMR spectrum of Exopolysaccharide in $\mathrm{D}_{2} \mathrm{O}$ at 90 ${ }^{\circ} \mathrm{C}$

Scanning Electron Microscopic analysis of EPSS

The Micro structure of Exopolysaccharide shows numerous pores and few small inter granular or intra granular pores. Particles are Agglutinating and present in the spherical shape in the sample.

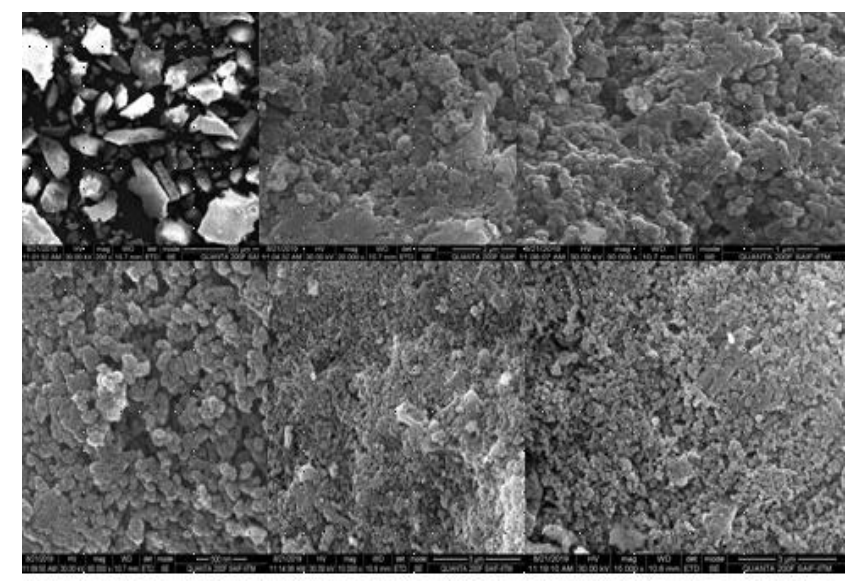

Fig.6 Scanning Electron Micrograph showing the surface of Bacillus megaterium PMSS12 exopolysaccharide at 3000X

\section{CONCLUSION}

It can be concluded that isolation of marine bacterial samples can provides variety of microbial strains for sources of new marine bio molecules. This research found that certain marine bacterial strains could be modified to produce exo polysaccharides of high molecular weight. that can be used as bioactive molecules.

\section{REFERENCES}

1. Freitas F, Alves DA, Reis MAM. Advances in bacterial exopolysaccharides: from production to biotechnological applications. Trends Biotechnol 29: 388-398, 2011.

2. Türetgen İ, Şanlı Yürüdü NÖ, Norden I. Biofilm formation comparison of the SANIPACKING cooling tower fill material against standard polypropylene fill material in a recirculating model water system. Turk J Biol 36: 313-318, 2012.

3. Bhaskar PV, Bhosle NB. Bacterial extracellular polymeric substance carrier of heavy metals in the marine food-chain. Environ Int 32 191-198, 2006.

4. İlhan Sungur E, Türetgen İ, Javaherdashti R et al. Monitoring and disinfection of biofilm-associated sulfate reducing bacteria on different substrata in a simulated recirculating cooling tower system. Turk J Biol 34: 389-397, 2010

5. Hinsa SW, O'Toole GA. Biofilm formation by Pseudomonas fluorescens WCS365: a role for LapD. Microbiology 152 1375-1383, 2006.

6. Poli A, Anzelmo G, Nicolaus B. Bacterial exopolysaccharides from extreme marine habitats: production, characterization and biological activities. Mar Drugs 8: 1779-1802, 2010.

7. Satpute SK, Banat IM, Dhakephalkar PK et al. Biosurfactants, bioemulsifiers and exopolysaccharides from marine microorganisms. Biotechnol Adv 28: 436-450, 2010.

8. Martins PSO, de Almeida NF, Leite SGF. Application of a bacterial extracellular polymeric substance in heavy metal adsorption in a co-contaminated aqueous system. Braz J Microbiol 39: 780-786, 2008.

9. Moppert X, Le Costaouec T, Ragunenes G et al. Investigations into the uptake of copper, iron and selenium by a highly sulphated bacterial exopolysaccharide isolated from microbial Mats. J Ind Microbiol Biot 36: 599-604, 2009.

10. Liu CT, Chu FJ, Chou CC et al. Antiproliferative and anticytotoxic effects of cell fractions and exopolysaccharides from Lactobacillus casei 01. Mutat Reshttp://www.sciencedirect. com/science/journal/13835718 721: 157-162, 2011.

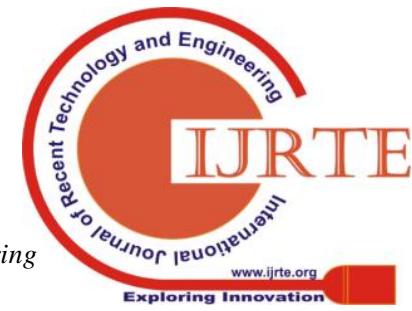




\section{Characterization of Exopolysaccharides Produced by Marine Bacillus Megaterium}

11. Kocharin K, Rachathewe P, Sanglier JJ et al. Exobiopolymer production by Ophiocordyceps dipterigena BCC 2073: optimization, production in bioreactor and characterization. BMC Biotechnol 10: 51, 2010.

12. Fett WF. Bacterial exopolysaccharides: their nature, regulation and role in host-pathogen interactions. Curr Topics Bot Res 1: 367-390, 1993

13. De Vuyst L, Degeest B. Heteropolysaccharides from lactic acid bacteria. FEMS Microbiol Rev 23: 153-177, 1999.

14. Morikawa M. Beneficial biofilm formation by industrial bacteria Bacillus subtilis and related species. J Biosci Bioeng 101: 1-8, 2006.

15. Muthusamy K, Gopalakrishnan S, Ravi TK et al. Biosurfactants: properties, commercial production and application. Curr Sci 94: 736-747, 2008.

16. Olbrich H. The Molasses. Biotechnologie-Kempe GmbH Publishers. Kleinmachnow, Germany; 2006.

17. Shukla P, Patel N, Rao RM et al. Isolation and characterization of polyhydroxyalkanoate and exopolysaccharide producing Bacillus sp. PS1 isolated from sugarcane field in Bhilai, India. J Microbial Biochem Technol 3: 033-035, 2011.

18. Radhakrishnan I, De SB, Nath B. Evaluation of the loading parameters for anaerobic digestion of cane molasses distillery wastes. Water Poll Control Fed 41: R431-R440, 1969.

19. Anju, P., Milind, N. \& Santosh Kumar, D. 2010. Hemolysin, Protease, and EPS Producing Pathogenic Aeromonas hydrophila Strain An4 Shows Antibacterial Activity against Marine Bacterial Fish Pathogens. Journal of Marine Biology, 10: 1-9.

20. Lekshmi Gangadhar and P. K Praseetha, A Green Approach to Sustainable Energy using Quantum Dots, International Journal of Recent Technology and Engineering, ISSN: 2277-3878, Vol. 8 , 345-350, 2019.

21. Lekshmi Gangadhar and P. K Praseetha, Identification and Molecular Phylogenetic Relationship of Selected Medicinal Plants-Ethano Medicinal Importance, Indian Journal of Public Health Research \& Development, ISSN: 0976-0245, Vol. 10,14-18, 2019.

22. Bragadeeswaran, S., Jeevapriya, R., Prabhu, K., Rani, S. S., Priyadharsini, S. \& Balasubramanian, T. 2011. Exopolysaccharide production by Bacillus cereus GU812900, a fouling marine bacterium. African Journal of Microbiology Research, 5: 41244132.

23. Poli A, Anzelmo G, Nicolaus B. Bacterial exopolysaccharides from extreme marine habitats: production, characterization and biological activities. Mar Drugs 2010;8:1779-802.

24. Siddharth Deshmukh, Pradnya Kanekar, Rama Bhadekar, 2017. Int J Pharm Pharm Sci, Vol 9, Issue 10, 146-151.

25. Manal S. Selim, Sahar S. Mohamed, Mohsen M. Asker, Abeer A.A Salama, Heba M.I Abdallah, Noha N. Yassen, Journal of Applied Pharmaceutical Science 8 (08); 2018: 001-011 